\title{
Obcy w kuchni. Jedzenie jako sposób realizacji opozycji ,swoje-obce” i ,arystokratyczne- plebejskie" w kulturze rosyjskiej do XIX w.
}

\section{Etapy rozwoju kuchni staroruskiej i jej charakter}

Kuchnia narodowa bez wątpienia jest jednym z elementów budujących tożsamość - narodową czy środowiskową. Aby jednak ta cecha tożsamościowa mogła się ujawnić, konieczna staje się obecność „innego”, „obcego”1, z którym można się skonfrontować i porównać. Narodowa kuchnia rosyjska nie należy tu do wyjątku. Jej formowanie się było procesem długotrwałym, silnie skorelowanym z kształtowaniem się państwowości rosyjskiej, a wcześniej ruskiej.

Proces ten, jak pisze znawca rosyjskich kulinariów, Wiliam Pochlebkin, dzieli się na kilka etapów. Pierwszy z nich, najdawniejszy, a zarazem najdłuższy, trwający umownie od IX do XVI w., to etap kuchni staroruskiej² Już w tym najodleglejszym okresie jej rozwoju można mówić o kuchni narodowej (pamiętając jednak o tym, że nie miała ona wiele wspólnego z tym, co dziś potocznie skłonni jesteśmy uważać za kuchnię rosyjską) jako o czynniku budującym i podkreślającym poczucie tożsamości narodowej. Tak mogło stać się jednak dopiero w obliczu wroga, czyli plemion tatarsko-mongolskich, które na początku XIII w. podbiły i podporządkowały sobie Ruś. Wroga w tym wypadku należy potraktować wła-

${ }^{1}$ Szerzej o pojęciu „obcości” zob. np. Literackie portrety Innego. Inny i Obcy w kulturze, cz. 2, red. P. Cieliczko i P. Kuciński, Warszawa 2008.

${ }^{2}$ Po nim nastąpiły kolejno: okres kuchni Państwa Moskiewskiego (XVII w.), kuchnia epoki Piotra I i Katarzyny II (przypadająca na XVIII w.), etap tzw. kuchni petersburskiej (trwający od końca XVIII w. do lat 60. XIX stulecia) i ostatni, stosunkowo krótki etap narodowej kuchni rosyjskiej, który trwał około czterech dziesięcioleci i zakończył się na przełomie XIX i XX w. W odniesieniu do okresu porewolucyjnego Pochlebkin pisze o „kuchni radzieckiej”, która również formowała się etapami, przyjmując wpływy nierosyjskie - w tym kontekście „obce”. Zob. В. Похлебкин, Национальные кухни наших народов, Москва 2006, s. 31-46; Zob. też Е. Щербакова, О. Корнилова, История русской кухни, Челябинск 2010, s. 4-11. 
śnie jako „obcego”, którego obecność skonsolidowała Rusinów na różnych płaszczyznach życiowych, w tym w tej dotyczącej zwyczajów żywieniowych. Znamienne jest, że trwający około dwóch wieków czas uzależnienia politycznego nie miał znaczącego wpływu na sposób odżywiania się mieszkańców ziem ruskich. Należy odnotować, że przez cały ten okres ruskie kulinaria okazały się odporne na obce, tatarskie wpływy. Wobec miernych możliwości czynnego oporu, jakie mieli Rusini, utrzymanie własnych tradycji było jednym z warunków zachowania tożsamości. Niechęć wobec kuchni obcego i odporność na jej wpływy świadczy w dużej mierze o świadomości własnej odrębności kulturowej i przekonaniu o jej wartości. Można więc powiedzieć, że ów najdawniejszy i najdłuższy okres dał mocne podwaliny pod kształtowanie się kuchni narodowej, będącej czynnikiem budującym poczucie tożsamości narodowej. Niebagatelną rolę w jej kształtowaniu się odgrywała religia chrześcijańska; opór mieszkańców podbitych ziem wobec przyjmowania obyczajów (w tym żywieniowych) „pogan” zdaje się zatem tym bardziej zrozumiały i uzasadniony ${ }^{3}$.

Jaka zatem była ta pierwotna kuchnia ruska i czym się charakteryzowała? Nie była ona szczególnie wymyślna i różnorodna, ale na pewno sycąca i — biorąc pod uwagę współczesne zalecenia dietetyczne — dość zdrowa. Co prawda okres, o którym mowa, czyli wieki od IX do XVI, jest pod względem kulinarnym najsłabiej udokumentowany, ale wiele informacji na temat jego schyłku dostarcza Domostroj (Домострой). Ten pochodzący z połowy XVI stulecia zabytek, którego tytuł można tłumaczyć jako „prowadzenie domu”, jest zarówno poradnikiem dotyczącym różnych dziedzin życia (przeznaczonym wszakże dla zamożniejszej części społeczeństwa, w tym dla kupców), jak i swego rodzaju książką kucharską, oferującą zamiast instrukcji wykonania określonych potraw długie ich wykazy, skonstruowane według klucza religijnego i podzielone na dania postne i mięsne. Podział ten wskazuje na istotną rolę religii jako czynnika organizującego życie codzienne w XVI w., czego dowodzi spora liczba dni postnych w ówczesnym kalendarzu prawosławnym: od 192 do $216^{4}$. A zatem wyznawca prawosławia w średniowieczu przez zdecydowaną większość roku musiał obchodzić się bez mięsa. Braki jakościowe rekompensował więc sobie liczbą potraw. W Domostroju przy-

${ }^{3}$ Według Jurija Łotmana specyfika kultury rosyjskiej, jej „pograniczność”, powoduje, że opozycja „swoje-obce” jest w sposób szczególny nasycona semiotycznie, a „obcy” nie zawsze postrzegany jest jednoznacznie i negatywnie. Np. dla członków średniowiecznej ruskiej wspólnoty rodowej obcość skutkowała wrogością i koniecznością obrony, ale w epokach późniejszych można zaobserwować odmienną tendencję: obcość otrzymuje status kulturowej normy, a to, co swoje, zostaje wypchnięte poza nawias kultury lub w najlepszym razie charakteryzuje się bardzo niską oceną w skali kulturowych wartości. Zob. Ю. Лотман, «Изгой» и «изгойничество» как сочиально-психологическая позиция в русской культуре преимущественно допетровского периода («Свое» и «чужое» в истории русской культуры, [w:] idem, История и типология русской культуры, Санкт-Петербург 2002, s. 222-225. Ten niejednoznaczny stosunek do obcości znajduje potwierdzenie również w rosyjskiej kulturze kulinarnej.

${ }^{4}$ Różnica była wynikiem m.in. ruchomej daty Wielkanocy oraz długości niektórych postów w poszczególnych latach. 
wołuje się ich blisko 140. Wielość ta jest jednak pozorna i nieco myląca, ponieważ potrawy te, choć różnią się nazwami, sporządzane były z bardzo ograniczonego wyboru składników, a różnice polegały często na zastosowaniu odmiennej obróbki cieplnej. Wśród postnych dań Domostroj wymienia potrawy z ryb: uchę — zupę przygotowywaną z jednego, wybranego gatunku ryb, czasem wędzonych lub suszonych, ryby gotowane, wędzone lub suszone i kawior ziarnisty albo prasowany. Oprócz ryb ważne miejsce zajmowały produkty zbożowe, przede wszystkim różnego rodzaju kasze: gryczana, żytnia, jęczmienna, orkiszowa i tzw. zielona (wytwarzana z zielonego żyta), przygotowywane w sposób uwarunkowany specyfiką tradycyjnego ruskiego pieca ${ }^{5}$, poza tym kulebiaki z farszami warzywnymi, rybnymi lub grzybowymi i jedna z najstarszych wschodniosłowiańskich potraw - bliny. Wśród dań mięsnych w XVI w. przeważała dziczyzna - ptactwo (pieczone łabędzie, żurawie, czaple, cietrzewie i kuropatwy) oraz mięso z łosia, ale też prosięta $\mathrm{z}$ rożna, polewki z domowego drobiu z szafranem, mięso solone z czosnkiem i przyprawami korzennymi, a także galarety.

\section{Wiek XVI i XVII: zderzenie z kulinarnymi wpływami tatarskimi i polskimi}

Wspomniany podział na potrawy postne i mięsne miał jeszcze inny wymiar: przez długie wieki na Rusi nie łączono z sobą produktów mącznych i mięsnych. Zmianę w tej dziedzinie przyniósł dopiero przełom XVI i XVII stulecia — wtedy na stałe do rosyjskiej kuchni zawitała np. „łapsza” (лапиа), czyli makaron z mięsnymi dodatkami. Co ciekawe, potrawa ta jest zapożyczeniem tatarskim, podobnie jak suszone morele, winogrona i rodzynki oraz arbuzy i melony. Wszystkie te produkty zostały przejęte właśnie od Tatarów po włączeniu do Rusi Chanatów Kazańskiego i Astrachańskiego w połowie XVI w. To dobrowolne zapożyczenie można tłumaczyć tym, że tym razem to Rusini w konfrontacji z Tatarami byli stroną silniejszą, dominującą, a co za tym idzie nie musieli obawiać się o ciągłość własnej tradycji i swoją tożsamość. Obcy, który jeszcze stosunkowo niedawno stanowił zagrożenie, teraz okazał się stroną słabszą, podporządkowaną.

Następny etap w rozwoju narodowej kuchni rosyjskiej to XVII w., kiedy można już mówić o końcu epoki kuchni staroruskiej, średniowiecznej. Początek nowego okresu to znów kolejna konfrontacja z obcym — zarówno polityczna, jak i kulinarna. Tym razem w roli obcego i jednocześnie najeźdźcy wystąpił „Lach”. Zwyczaje Polaków związane z jedzeniem były w Moskwie nie do zaakceptowania, budziły wielkie emocje, a wreszcie stały się rozstrzygające w kwestii rozróżnienia „swójobcy" - kwestii tym gorętszej, że w tym wypadku obcy był synonimem wroga.

Jeden z pierwszych przykładów owego podziału na obcych i swoich miał miejsce w czasie uczty weselnej Dymitra Samozwańca z Maryną Mniszchówną

${ }^{5}$ Tradycyjny ruski piec nie ma płyty grzewczej, a zatem przygotowywane w nim potrawy nie są gotowane, lecz raczej pieczone. 
w 1609 r. Panna młoda posługiwała się wówczas przywiezionym przez siebie $\mathrm{z}$ domu dwuzębnym widelcem, podczas gdy miejscowi, zgodnie z zakorzenionym od dawna obyczajem, wszystkie potrawy jedli łyżką lub po prostu rękoma. Widelec w ręku polskiej żony cara podkreślał jej obcość na ruskim dworze, a odczuciu tej obcości towarzyszyły niepokój i obawa, wywołane przez skojarzenia, jakie w miejscowych budził widelec — na moskiewskim dworze kojarzył się on jednoznacznie z widłami, a więc atrybutem diabła ${ }^{6}$. Niektórzy, zwłaszcza najbardziej zagorzali wrogowie Dymitra, postrzegali zatem Marynę nie jako prawowitą carycę, ale wspólniczkę szatana.

Jako drugi przykład może posłużyć stosunek prawosławnych Moskwian do spożywania mięsa cielęcego - jego jedzenie objęte było rygorystycznym zakazem, w dużej mierze opierającym się na przekonaniach religijnych. W tym kontekście ostentacyjne spożywanie cielęciny przez Dymitra Samozwańca było przede wszystkim przejawem jawnego lekceważenia ogólnie przyjętych obyczajów, tym bardziej obraźliwego, że obyczaje te dotyczyły religii, co w konsekwencji jednoznacznie sytuowało go po stronie „obcych”. Obie te okoliczności wzmagały podejrzenia co do autentyczności Dymitra jako nowego cara i doprowadziły w końcu do tzw. cielęcego buntu bojarów?

Traktowaniu kuchni ruskiej jako elementu tożsamości narodowej sprzyjał z pewnością fakt, że była ona autentycznie „narodową” aż do XVII w., co oznacza, że do tego czasu cechowała ją uniwersalność i podobna dostępność dla reprezentantów wszystkich warstw społecznych. Istniały wprawdzie pewne różnice, ale miały one charakter raczej ilościowy niż jakościowy. W wyższych warstwach społecznych jedzono po prostu więcej, na ogół używając jednak tych samych składników co w warstwach niższych. Do arystokratycznych zbytków należały wina sprowadzane z Grecji i Francji (małmazja i wina burgundzkie) oraz takie owoce, jak figi, daktyle czy cytryny.

\section{Piotr I i narodziny kuchni arystokratycznej}

Wiek XVII jest początkiem przełomu, a właściwie rozłamu w kuchni ruskiej — wówczas zaczyna się zarysowywać nieistniejący wcześniej podział na kuchnię arystokratyczną i plebejską. Doszło do niego w dużej mierze za sprawą wprowadzenia monopolów na m.in. kawior, łososie czy miód, a także na skutek całkowitej rezygnacji z wymiany towarowej na rzecz wymiany pieniężnej. Z powodu tych zmian czym innym dysponowali np. bojarzy, a co innego zostawało

${ }^{6}$ Widelec dopiero w XX w. — za sprawą władzy radzieckiej — znalazł się w powszechnym użyciu, wcześniej był narzędziem arystokratycznym, a sam rzeczownik вилка ('widelec') wszedł do obiegu językowego po ponad stuleciu od wesela Maryny Mniszchówny. Zob. http://statehistory. ru/420/Kak-poyavilas-vilka-na-Rusi/ (dostęp: 19.11.2017).

${ }^{7}$ W 1606 r. na wieść o tym, że Dymitr je cielęcinę, rozgniewany tłum wdarł się na Kreml w przekonaniu, że car musi być Polakiem. Zob. http://izvestia.ru/news/316003; http://wap.starovery.unoforum.pro/?1-2-40-00000143-000-0-0 (dostęp: 19.11.2017). 
do dyspozycji chłopom. Kuchnia chłopska w tym czasie staje się coraz uboższa w odróżnieniu od kuchni warstw uprzywilejowanych - coraz bogatszej i bardziej wymyślnej. W XVIII w. kuchnia arystokratyczna właściwie traci swój narodowy charakter, czasem nawet otwarcie zrywa z rodzimą tradycją kulinarną ${ }^{8}$. Dzieje się tak za sprawą Piotra I, którego ambicje doścignięcia Europy Zachodniej realizowały się również w sferze kulinarnej. Zachodnie mody na grunt kuchni rosyjskiej przeszczepiali kucharze, których monarcha sprowadzał z Niemiec i Holandii ${ }^{9}$. Wyparli oni niemal całkowicie kucharzy miejscowych, wywodzących się z chłopstwa.

Cudzoziemcy przywieźli z sobą nowe przepisy, naczynia i technologie przyrządzania potraw. Wśród nowości na arystokratycznych stołach pojawiły się zakąski — w ich skład, oprócz niemieckich kanapek, holenderskich serów i masła, wchodziły tradycyjne rosyjskie solone mięsa, kawior czy wędzone lub suszone ryby. Zetknięciu z obcą obyczajowością kulinarną w XVIII w., w odróżnieniu od wieków poprzednich, nie towarzyszyły ostre konfrontacje polityczne, choć promowanie obcych wzorców nie było całkowicie spontaniczne i miało charakter nieco opresyjny, zwłaszcza za panowania Piotra I. Za przykład niech posłuży wydany przez niego w 1718 r. ukaz o tzw. assamblejach ${ }^{10}$, na mocy którego uregulowano kwestię napojów — od tego momentu ktoś, kto nie chciał stać w opozycji do oficjalnej władzy (wyłączając chłopów), musiał pić kawę i herbatę. Spożywanie tych, wówczas jeszcze kosztownych napojów, miało być wyznacznikiem postępu i przynależności do kultury zachodniej. W tym celu Piotr I nakazał wzniesienie w Petersburgu pawilonu herbacianego i domu kawowego na wzór zachodnich kawiarni. W opozycji do kawy i herbaty zostały postawione rodzime, tradycyjne kwas i piwo jako synonimy zacofania, trywialności i plebejskości.

Gdy Piotr I wprowadzał ukaz o assamblejach, herbata w Rosji była znana dopiero od osiemdziesięciu lat ${ }^{11}$, ale już od drugiej połowy XVII w. regularnie ją importowano i sprzedawano, przede wszystkim w Moskwie. Trudno wytłumaczyć przyczyny, dla których w ekspresowym tempie około czterdziestu lat herbata przyjęła się w Rosji i z nowinki, początkowo budzącej obawy, stała się

8 Zob. И. Свирида, Функичии еды в иностранных описаниях России XVI-VXII вв., [w:] Коды повседневности в славянской культуре: еда и одежда, red. Н. Злыднева, Санкт-Петербург 2011, s. 268.

${ }^{9}$ Co ciekawe, monarcha gustował w tradycyjnych potrawach rosyjskich, bardzo gorących, natomiast $\mathrm{z}$ nowości zachodnioeuropejskich szczególnie upodobał sobie mocne wina gronowe. Zob. Ю. Лотман, Е. Погосян, От кухни до гостиной, [w:] idem, История и типология русской культуры, Санкт-Петербург 2002, s. 261.

${ }^{10}$ Assambleje były spotkaniami towarzyskimi, podlegającymi ścisłej regulacji władz, mającymi na celu wprowadzenie i upowszechnienie zachodnioeuropejskich wzorców zachowań. Zob. np. W.A. Serczyk, Piotr I Wielki, Wrocław 1990, s. 205-207.

${ }^{11}$ W 1638 r. carski poseł Wasilij Starkow przywiózł na dwór Aleksego Michajłowicza w charakterze daru od mongolskiego chana $64 \mathrm{~kg}$ herbacianego suszu. Zob. В. Похлебкин, Чай, Москва 2005, s. 108-115. 
najchętniej pitym napojem ${ }^{12}$. Początkowo jednak, ze względu na cenę, była elementem kulinarnego kodu identyfikującego przynależność do wyższych warstw społecznych. Dopiero w XIX w., wraz ze wzrostem dostępności, jej rola jako wyznacznika arystokratyczności zaczęła maleć.

Dzieło Piotra I kontynuowały jego następczynie: córka Elżbieta i Katarzyna II, która z kolei preferowała kucharzy francuskich. Przybywali oni do Rosji w poszukiwaniu zajęcia po tym, jak po rewolucji utracili miejsca pracy w domach rodzimej arystokracji. Za sprawą mistrzów kuchni francuskiej tradycyjne rosyjskie traktiernie zaczęły zmieniać swe oblicze, by w krótkim czasie przekształcić się w restauracje. W XVIII w. rozpoczyna się proces przyswajania, czy raczej oswajania, obcej tradycji i dostosowywania jej do miejscowych warunków. Proces ,europeizacji” kuchni rosyjskiej najszybciej zachodził w stolicy — Sankt Petersburgu, najwolniej na prowincji i w Moskwie, która była strażniczką rosyjskiej tradycji aż do połowy XIX w., kiedy to prym w środowisku arystokratycznym zdecydowanie wiodła kuchnia francuska.

\section{Wiek XIX: powrót do rodzimej tradycji kulinarnej}

Lata 70. XIX w. to kolejny zwrot w kuchni rosyjskiej — tym razem w stronę tradycji - i odwrót od cudzoziemszczyzny. Jego przyczyn należy upatrywać w różnorodnych zjawiskach, np. w rozbudowie sieci kolejowej, dzięki której do centrum imperium zbliżyły się jego najodleglejsze krańce, co poskutkowało wzrostem zainteresowania kulturą tych dalekich obszarów, w tym kulturą kulinarną. Największy jednak wpływ na zmianę gustów gastronomicznych miała reforma uwłaszczeniowa $z$ lat 60 . XIX stulecia. Po jej wprowadzeniu do miast napłynęło wielu chłopów, a wśród nich również utalentowani kucharze, którzy znajdowali zatrudnienie zarówno w domach szlacheckich, jak i w restauracjach. To oni zaczęli wyznaczać nowe (choć w zasadzie stare) tendencje w rosyjskiej gastronomii. Dzięki nim doszło do odnowienia i rozpowszechnienia kuchni narodowej, która w dużej mierze opierała się na kuchni chłopskiej.

Gastronomiczna historia zatoczyła koło - ponownie ,swoje” oznaczało rzeczywiście to, co swoje. Ten trwający raptem kilka dziesięcioleci okres powrotu do korzeni kuchni rosyjskiej zakończył się wraz z rewolucją bolszewicką, która stała się początkiem całkiem nowej epoki nie tylko politycznej, lecz także kulinarnej $^{13}$.

12 Przynajmniej w Moskwie. Petersburg był w tym wypadku oporny — być może dlatego, że zdecydowanie preferował kulturę Zachodu, a herbatę (pochodzącą przecież ze Wschodu) upodobali sobie mieszkańcy bardziej przywiązani do dawnych tradycji Moskwy. Sam Piotr I jednak kojarzył picie herbaty z obyczajem zachodnioeuropejskim i tym motywował swój nakaz.

${ }^{13}$ O zjawisku, jakim była kuchnia radziecka, zob. I. Głuszczenko, Sowiety od kuchni. Mikojan i radziecka gastronomia, przeł. M. Nowak, Warszawa 2012. 


\section{Opozycja „swoje-obce” i ,arystokratyczne-plebejskie” na przykładach literackich}

Wyrazistych, choć niebyt licznych ${ }^{14}$ przykładów tego, jak na płaszczyźnie kulinarnej „swoje” splata się z „obcym”, a pierwiastek plebejski z arystokratycznym, dostarcza literatura rosyjska XIX stulecia. Bohater powieści-poematu Nikołaja Gogola ${ }^{15}$ Martwe dusze (Mepmвые души) — właściciel ziemski Sobakiewicz twardo stoi na pozycji obrońcy ruskiej tradycji. W swoich poglądach na otaczającą rzeczywistość wyraźnie przeciwstawia to, co swoje, rodzime i dobrze znane, „obcemu”, przy czym to „obce” rozumiane jest jako obce kulturowo i społecznie, a uosabia je kuchnia francuska i arystokratyczna. Sobakiewicz jest prowincjuszem, mocno przywiązanym do rodzimych smaków, wśród których poczesne miejsce zajmują kapuśniak i tzw. niania — danie sycące i ciężkostrawne, na które składa się barani żołądek faszerowany kaszą gryczaną, nóżkami i móżdżkiem. W taki oto sposób argumentuje on wyższość tradycyjnej kuchni rosyjskiej nad francuską:

Мне лягушку хоть сахаром облепи, не возьму ее в рот, и устрицы тоже не возьму: я знаю, на что устрица похожа! Возьмите барана. Это не те фрикасе, что делаются на барских кухнях из баранины, какая суток по четыре на рынке валяется! Это все выдумали доктора немцы и французы, я бы их перевешал за это! Выдумали диету, лечить голодом! [...] У меня не так. У меня когда свинина — всю свинью давай на стол, баранина — всего барана тащи, гусь - всего гуся! Лучше я съем двух блюд, да съем в меру, как душа требует ${ }^{16}$.

Warto zwrócić uwagę, że dla Sobakiewicza kwintesencję dania „pańskiego”, arystokratycznego i wielkomiejskiego stanowią ostrygi (które wyraźnie go brzydzą), wymienione w jednym szeregu z żabą, stereotypowo kojarzoną z kuchnią francuską.

Nie tylko to, co jedzono, lecz także miejsce, w którym spożywano posiłek odzwierciedlało przynależność do określonej warstwy społecznej. Odstępstwo w tej kwestii od przyjętych norm ujawniało silną korelację pomiędzy analizowanymi tu opozycjami. W powieści Urwisko (Обрыв) Iwana Gonczarowa babka głównego bohatera, szlachcianka ze świetnego rodu, kobieta dumna i gospodarna, unosi się honorem, gdy jej dorosły wnuk bez cienia zażenowania przyznaje, że jada w traktierni. W ten sposób wyraża on swoją obojętność wobec przesądów społecznych, podczas gdy dla babki jedzenie prostych, według niej ordynarnych, potraw w rodzaju makaronu czy kaszy (лапша да каша) jest synonimem duchowego upadku szlachcica.

${ }^{14}$ Przyczyn takiego stanu rzeczy Pochlebkin upatruje w specyfice klasycznej literatury rosyjskiej, która koncentrując się na wielkich zagadnieniach społecznych czy kwestiach moralnych, nie pozostawiła sobie możliwości rozwinięcia np. nurtu gastronomicznego. Zob. В. Похлебкин, Из истории русской кулинарной культуры, Москва 2008, s. 27-30.

15 Pochlebkin nazywa Nikołaja Gogola najbardziej „kulinarnym” klasykiem literatury rosyjskiej pierwszej połowy XIX w. Zob. В. Похлебкин, Из истории русской..., s. 194.

${ }^{16}$ Н. Гоголь, Мертвые души, Москва 1968, s. 93. 
Сегодня наготовили, вдруг приехал и пропал! На что похоже? И что скажут люди: обедал у чужих — лапшу да кашу; как будто бабушке нечем накормить! [...]

- В трактир пойду.

- В трактир! - с ужасом сказала бабушка. [...]

- Кто же вас пустит в трактир? [...]

— Разве ты ходишь по трактирам? - строго спросила бабушка.

— Я всегда в трактире обедаю ${ }^{17}$.

Równie znaczące ujęcie znajdziemy w jednym z pierwszych rozdziałów Anny Kareniny (Анна Каренина) Lwa Tołstoja, w którym Konstanty Lewin i Stiepan Obłoński odwiedzają restaurację hotelową w zachodnioeuropejskim stylu. Obłoński — arystokratyczny sybaryta — zaprasza przyjaciela na ostrygi flensburskie, bo — chociaż ostendzkie uchodzą za wykwintniejsze — to właśnie ich zabrakło. Lewin natomiast przejawia absolutną obojętność wobec ostryg ${ }^{18}$ i najchętniej zjadłby miskę kapuśniaku lub kaszy, ale tych zwykłych, trywialnych rosyjskich dań elegancka restauracja nie serwuje:

— Так что ж, не начать ли с устриц, а потом уж и весь план изменить? А?

- Мне все равно. Мне лучше всего щи и каша; но ведь здесь этого нет.

— Каша а ла рюсс, прикажете? - сказал татарин, как няня над ребенком, нагибаясь над Левиным ${ }^{19}$.

Lewin, choć przecież — tak jak Obłoński — jest szlachcicem, żyje jak plebejusz, jak chłop - na wsi, w spartańskich warunkach, ciężko pracuje fizycznie i dlatego woli prostą wiejską strawę od wyrafinowanych restauracyjnych dań o obco brzmiących nazwach. W ten sposób autor ukazuje obcość (i inność) Lewina w środowisku szlacheckim. Na prosty pożywny obiad można było wstąpić do jednej z licznych traktierni, ale bohaterowi, będącemu arystokratą, nie wypadało pójść, zamiast do eleganckiej hotelowej restauracji, do zwykłej gospody. Jego obecność nie byłaby tam naturalna, budziłaby zdziwienie i ciekawość, co oznacza, że i tam byłby obcy, bo traktiernie były przeznaczone przede wszystkim dla pospólstwa - zaglądali do nich kupcy, chłopi, biedni studenci - a status szlachcica określał w niemałym stopniu sposób odżywiania się i miejsce, w którym jadał.

Szczególnego smaku przywołanej powyżej scenie dodaje to, że kelner obsługujący gości jest Tatarem i wszystkie nazwy potraw „,dla własnej satysfakcji powtarza według karty" po francusku. Dla podkreślenia wzajemnej nieprzystawalności elementów składających się na ową scenę — wszystkie one właściwie są względem siebie obce - nazwy potraw przytoczone są fonetycznie: począwszy od „kaszy alarius” do „sup prentanier, tiurbo sos bomarsze, pulard a lestraga i maseduan de friui" (суп прентаньер, тюрбо сос Бомарше itd.).

17 И. Гончаров, Обрыв, Москва 1950, s. 212-213.

${ }^{18} \mathrm{~W}$ przeciwieństwie do Gogolowskiego Sobakiewicza w Lewinie ostrygi nie budzą obrzydzenia, co wyraźnie sytuuje go po stronie elity szlacheckiej.

19 Л. Толстой, Анна Каренина, t. 1, Москва 1973, s. 39. 
Przytoczone przykłady literackie ilustrują wyraźną korelację opozycji „,swoje-obce” i ,plebejskie-arystokratyczne”, obecną w rosyjskiej kulturze kulinarnej od stuleci.

\section{Bibliografia}

Głuszczenko I., Sowiety od kuchni. Mikojan i radziecka gastronomia, przeł. M. Nowak, Warszawa 2012.

Serczyk W.A., Piotr I Wielki, Wrocław 1990.

Гоголь Н., Мертвые души, Москва 1968.

Гончаров И., Обрыв, Москва 1950.

Домострой, Москва 2009.

Лотман Ю., «Изгой» и «изгойничество» как сочиильно-психологическая позиция в русской культуре преимущественно допетровского периода ("Свое» и «чужое» в истории русской культуры), [w:] idem, История и типология русской культуры, Санкт-Петербург 2002.

Лотман Ю., Погосян Е., От кухни до гостиной, [w:] idem, История и типология русской культуры, Санкт-Петербург 2002.

Похлебкин В., Из истории русской кулинарной культуры, Москва 2008.

Похлебкин В., Национальные кухни наших народов, Москва 2006.

Похлебкин В., Чай, Москва 2005.

Свирида И., Функциии еды в иностранных описаниях России XVI-VXII вв., [w:] Коды повседневности в славянской культуре: еда и одежда, red. Н. Злыднева, Санкт-Петербург 2011.

Толстой Л., Анна Каренина, Москва 1973.

Щербакова Е., Корнилова О., История русской кухни, Челябинск 2010.

\section{Źródła internetowe}

http://izvestia.ru/news/316003.

http://wap.starovery.unoforum.pro/?1-2-40-00000143-000-0-0.

http://statehistory.ru/420/Kak-poyavilas-vilka-na-Rusi/.

\section{Foreign in the kitchen. Food as a way to implement "familiar-foreign" and "patrician-plebeian" oppositions in Russian culture till 19th century}

\section{Summary}

The paper addresses the problem of eating habits as an identification code which defines affiliation to a particular community or a social layer. Till 17th century there was no distinction between aristocratic and plebeian dishes in Old Russian cuisine. 17th century brought differentiation between the diet of aristocracy and lower layers of society. During the reign of Peter the Great selection of dishes as well as the way of their preparation and eating became an identification code 
denoting belonging to the Western aristocratic culture. At the turn of the 18th and 19th centuries the division into aristocratic and plebeian kitchen was established. The changes in Russian cuisine were also related to attitude toward the foreign influences and often were politically motivated.

Literary source used in the paper is represented mostly by fragments of the works by Russian writers such as Nikolai Gogol, Ivan Goncharov and Leo Tolstoy.

Keywords: Russian cuisine identification code foreign, plebeian, patrician.

\section{Чужие на кухне. Еда как способ реализации оппозиции «свое-чужое» и «аристократическое- плебейское» в русской культуре до XIX столетия}

Резюме

В настоящей статье еда рассматривается как идентификационный код, определяющий принадлежность к данному общественному слою или группе. В древнерусской кухне не наблюдалось существенной разницы между плебейскими и аристократическими блюдами. Разница стала замечаться лишь только в XVIII столетии при Петре I, когда подбор блюд, способ их приготовления и способ приема пищи стали кодами, посредством которых определялась принадлежность к западной аристократической культуре. Это строгое разделение на «аристократическое» и «плебейское» в русской кухне упрочилось на рубеже XVIII и XIX столетий. Описываемые в статье перемены в русской кухне были связаны с отношением русских к чужим влияниям и довольно часто основывались на политических началах. В качестве иллюстративного литературного материала в статье использованы фрагменты романов Николая Гоголя, Ивана Гончарова и Льва Толстого.

Ключевые слова: русская кухня, идентификационный код, чужой, плебейский, аристократический. 